\title{
Challenging the EU's Economic Roles? \\ The Impact of the Eurozone Crisis on EU Images in China
}

\author{
Suet-Yi Lai \\ National Centre for Research on Europe \\ University of Canterbury \\ Kirkwood Village KD04, \\ Christchurch, New Zealand \\ E-mail: cherlai1212@yahoo.com.hk
}

Li Zhang

School of Political, Social and International Studies University of East Anglia Norwich Research Park, Norwich NR4 7TJ, UK E-mail: L.Zhang11@uea.ac.uk

Abstract: Since the outbreak of the 2008/2009 global financial crisis, the economic balance between the traditional developed economies and the emerging ones has changed drastically, including that between the European Union and China. While the EU and its Member States are preoccupied by the eurozone debt crisis, stagnant economic growth and high domestic unemployment, China raised as the world's second largest economy and one of the quickest growing consumer market. This paper explores the change in perception of the EU as an economic actor in the eyes of Chinese mainstream news media and national elites under such context. It argues that the strategic partnership could improve only if the two sides understand the mutual perception clearly. It is found that China has increased its leverage for bargaining vis-à-vis the EU as well as the capacity to give some help to the EU. Although the image of the EU as an economic powerhouse has been slightly weakened, it did not turn the heavily trade-oriented EU-China relations more comprehensive.

Keywords: elite interviews, EU-China economic relations, EU perception, eurozone debt crisis, media analysis 


\section{Introduction}

Since 2009, several of the eurozone member states have been engulfed by sovereign debt problems. First in Greece, which was followed by Ireland and Portugal, and then in Spain and Italy, fiscal difficulties cause economic as well as political instability. The debt crisis also poses challenge to the solidity of the European Monetary Union. The value of the common currency, the euro, has decreased continuously and significantly. Thus far, several rescue actions have been taken, namely European Union/International Monetary Fund joint bailout funds to Greece, Ireland and Portugal, creation of the European Financial Stability Fund as well as the European Stability Mechanism. However, financial situations in the indebted countries and fears for the viability of the eurozone have not been eased. Some commentators suggest that the debt-laden 'periphery' eurozone countries should exit the common monetary union and/ or default. Seemingly, such prolonged financial and economic turmoil may have compromised the European Union's image as a great economic power in the international arena. This analysis examines how the EU's economic might is perceived by one other great economic power, China, which by 2011 had overtaken Japan and become the world's second largest economy.

It is important to be aware of the perceptions as well as misperceptions of international actors because, as suggested by Jervis (1976), they help explain the policies and decisions taken by one international actor towards the other. Consequently, this paper interrogates the negative impact, if any, the eurozone debt crisis has had on the EU's external image as an economic power in the eyes of China, the bloc's second biggest trading partner and the world's largest foreign reserve holder, and contemplates how such imagery might influence EUChina economic and trade relations. The paper first outlines the external relations of the EU, as an economic power, with China, and then presents findings of a comparative study of the EU images in China before and after the outbreak of the sovereign debt crisis in the eurozone. Using datasets from media content analysis and qualitative interviews, this study explores the extent to which the eurozone debt crisis has challenged the image of the EU as an able economic actor in the eyes of Chinese mainstream news media and national elites and considers the implications for the EU-China strategic partnership. 


\section{The EU economic powerhouse and China}

Half a century of European integration resulted in removing national borders, overcoming historical conflicts, building a single market and currency, as well as generating a common trade policy. Without doubt, the Union has become an economic "powerhouse" of the world. In parallel, the EU has been trying to consolidate itself as a political union, first through European Political Cooperation (EPC) in the 1970s, the Common Foreign and Security Policy (CFSP) in the 1992 Maastricht Treaty, and now under the European External Action Service (EEAS) since December 2010. Yet, its image as an international economic actor has been undeniably much more prominent than as an international political actor.

Capitalising on its reputation as an international economic powerhouse, the EU signed a Trade Agreement with China in 1978, three years after the two partners formally established diplomatic relations. With the growing importance of economic relations, the 1978 Agreement was replaced by a Trade and Economic Cooperation Agreement in 1985. This latter agreement has governed relations between the two parties as well as granted most-favoured nation status for China and the EU. The 1989 Tiananmen Square incident led to the lowest point in the relationship, with Europe implementing a series of sanctions against China. ${ }^{1}$ While these sanctions have been gradually eased since the early 1990s, the arms embargo remains in force.

In 1995, the EU published its milestone policy on its long-term engagement with China (European Commission, 1995). Since then, the contacts between Europe and China have increased rapidly and their relations ameliorated. However, this amelioration was mostly in the areas of the economy and trade, with little change at the level of diplomatic and political relations. A turning point came in 1998, when the EU published its second policy paper on China designed to enhance EU-China relations to the level of a comprehensive partnership (European Commission, 1998). EU-China high-level official meetings were fully resumed and, furthermore, the mechanism for an annual EU-China Summit was launched. Symbolically, the EU's relationship with China has attained the same status as the EU-US, EU-Russia, and EU-Japan dialogues.

1 The research was first initiated by the National Centre for Research on Europe, University of Canterbury, New Zealand, in 2002. It identifies the external image of the EU and the attitude and opinions on the ASEM process in Asia-Pacific. For more details, see www.euperceptions.canterbury.ac.nz/, Holland et al., 2007; Holland \& Chaban, 2010. 
In 2003, relations were further boosted by the EU and China establishing a comprehensive strategic partnership (European Commission, 2003; China, 2003), which was further upgraded in 2010 to include foreign affairs, security matters and global challenges such as climate change and global economic governance.

In 2004, the enlarged EU became China's largest trading partner. Since then, the Union has been the most important destination for China's exports, China's top technology supplier, and the second ranked supplier to China after Japan. The EU is also one of the top five sources of foreign direct investment to China. On the other hand, China has become the EU's second largest trading partner, after the US, and the EU's biggest source of manufactured goods. From 2006 to 2010, according to EU Council statistics, EU trade with China grew by 11 per cent, while EU trade with the world grew by only 3 per cent, 2011 recorded another 5 per cent increase in EU imports from China (EU Council Secretariat, 2012). Nonetheless, the proliferation of trade has caused friction between China and the EU, especially over the huge trade deficit in favour of China. The imposition of anti-dumping/anti-subsidy duties and the non-recognition of China's market status economy are other issues for recurrent disputes between the two. As economic ties play such a crucial role in bilateral relations, the state of economy of either party matters significantly to the other. Consequently, a negative change in China's perception of the EU as an economic power after the outbreak of the eurozone debt crisis is anticipated.

Furthermore, since the introduction of euro, the single currency has been seen as an international currency and a potential alternative to the US dollar. Holding the world's largest foreign reserves, China has invested significantly in euro-denominated assets. Although there are no official statistics on the exact allocation of China's foreign reserve holdings, it is estimated that between half and two-thirds of its currency portfolio is in US dollars, between one-fifth and one-third has been invested in euro-denominated assets, while around one-tenth is a combination of British pounds, Japanese yen and other currencies $(\mathrm{Hu}$, 2010, pp. 8-9).

However, in the time when several eurozone economies are suffering from the sovereign euro debt crisis and poor economic performance, might China lose confidence in its most important trading partner? Would China perceive the EU to be less powerful economically? Moreover, would the crisis affect the external image of the euro as an international currency in general and for China's foreign reserve in particular? 
Although an increasing number of studies on Chinese perceptions of the EU have been conducted in both China and Europe in recent years, most of them have been focused on the general image of the EU (e.g., Holland et al., 2007; Holland \& Chaban, 2010; Men, 2006; Zhu, 2008; Shambaugh, 2008; Zhang 2011). Certainly, the image of the EU as an economic actor has always been an important element in those studies, as the Union's economic strength is the most widely recognised. Nonetheless, studies on the influence of the eurozone fiscal crisis on the EU's external images, particularly the EU as an economic actor, are largely absent. The eurozone debt crisis poses, thus far, the biggest challenge to the EU since it became an economic and monetary union. To what extent then does this challenge the EU's economic power image internationally as well as the image of the euro as an international currency?

In addition, this paper explores how material factors, such as financial difficulties in the eurozone in this case study, affect the perception and intersubjectivity between partners in international relations (China and the EU) through the social constructivism approach. Specifically, how the change in perception (subjective views) might influence the socialisation and interaction (objective facts) between partners is examined. The constructivist school, as applied here, emphasises the mutual constituting characteristic between agents and the structures which embrace their interaction (Wendt, 1992; 1994). Ideas play a crucial role in constructivism: ideas comprise goals, threats, fears, identities and any perception which affects the actors in the international system. Norms play a significant additional role.

Social constructivism challenges realism and liberalism which ignore ideational factors, suggesting that both normative and material structures play a role in international relations. Particularly, the notion of 'identity', which is believed to be shaped by both ideas and material structures, informs the interests and thus actions of actors, and occupies a central role (Wendt, 1992; Ruggie, 1998). Social constructivists argue that the identity of the agent informs their behaviour in international relations, including inter-regional ones.

Based upon intersubjectivity, the identity of agents and structure of the international realm are formed and reformed continuously. Yet, due to an absence of complete information and lack of rationality of states as actors, social constructivists argue that the evaluation of costs and benefits rests substantially on cognitive factors. In other words, past experiences and ideas help to shape perceptions of costs and benefits. Applying this to the case study, material factors including the large volume of trade between the EU and China, the EU-China comprehension strategic partnership since 2003, China's holding of a large 
amount of euro-based foreign reserves together with the prolonged financial difficulties in the euro area are also all determinants of perceptions towards the EU as both an economic partner as well as of the euro as a credible international currency in the eyes of China.

\section{Methodology}

This research employs two complementary and empirically rich datasets from two stages of the project 'The EU through the Eyes of Asia-Pacific' spanning the 2006-2012 period. $^{2}$ It uniquely and innovatively compares Chinese news media representation and Chinese elites' views on the EU as an economic power and the role of the euro in 2006/2007 (before the outbreak of the eurozone debt crisis) and 2011 (after the outbreak of the eurozone debt crisis).

The media data involves the systematic daily news media analysis for twelve months in 2006 (January-December) and the first six months of 2011 (JanuaryJune). Four significant news outlets were monitored: the People's Daily (the most authoritative daily), China Daily (the most popular and prestigious Englishlanguage daily), the International Finance News (a popular and reputable business daily) and the prime-time news bulletin, "Xinwen Lianbo", on CCTV1 at $7 \mathrm{pm}$ (the most widely disseminated television news programme). As the Chinese media are closely controlled by the Chinese government, and to a larger extent speak as "throat and tongue" of the government, particularly in foreign news reporting, we argue that this Chinese media EU reportage reflects the Chinese government's opinion (or at least does not deviate substantially from the government's view). The EU-related news items (3,349 articles) were identified and collected from the four selected media outlets. Identical content analysis categories were used to explore EU media imagery in the news before and after the crisis. The coders, all native speakers of Mandarin, were formally trained in the methodology of content analysis. The intensity, framing, evaluation and contextualisation of the EU in these news items were studied both quantitatively and qualitatively. The news about the eurozone sovereign debt crisis in 2011 was examined in particular detail.

The elite data comprises responses from the face-to-face interviews with four distinct cohorts: government officials, business people, and intellectuals from civil society and media professionals. Thirty-one interviews were conducted in

2 These include the European Commission, the European Parliament, the European Central Bank, the European Court of Justice and the European Council. 
Shanghai in March-July 2007 and sixty in Beijing in June 2011. All interviews were semi-structured, in-depth and lasted from thirty minutes to one hour. An identical protocol containing 18 questions was used. Each interview was transcribed verbatim in Chinese and then translated into English (with the translation checked by a bilingual researcher). Such substantial datasets were examined both quantitatively and qualitatively to illustrate how Chinese stakeholders perceive the economic power of the EU and the euro.

\section{The data: changes in the media portrayal of EU economic power}

The EU, its institutions ${ }^{3}$ and/or its officials were reported in 1,988 news items from January to December in 2006, and in 1,361 articles from January to June 2011. The data show that the 2011 monthly average of EU coverage across all monitored Chinese dailies was higher than that found for 2006 (Fig. 1), especially in the People's Daily. In the television news, however, the degree of interest towards covering the EU remained modest and the same.

Figure 1. Monthly coverage of EU-related news in four Chinese media outlets, 2006 and 2011

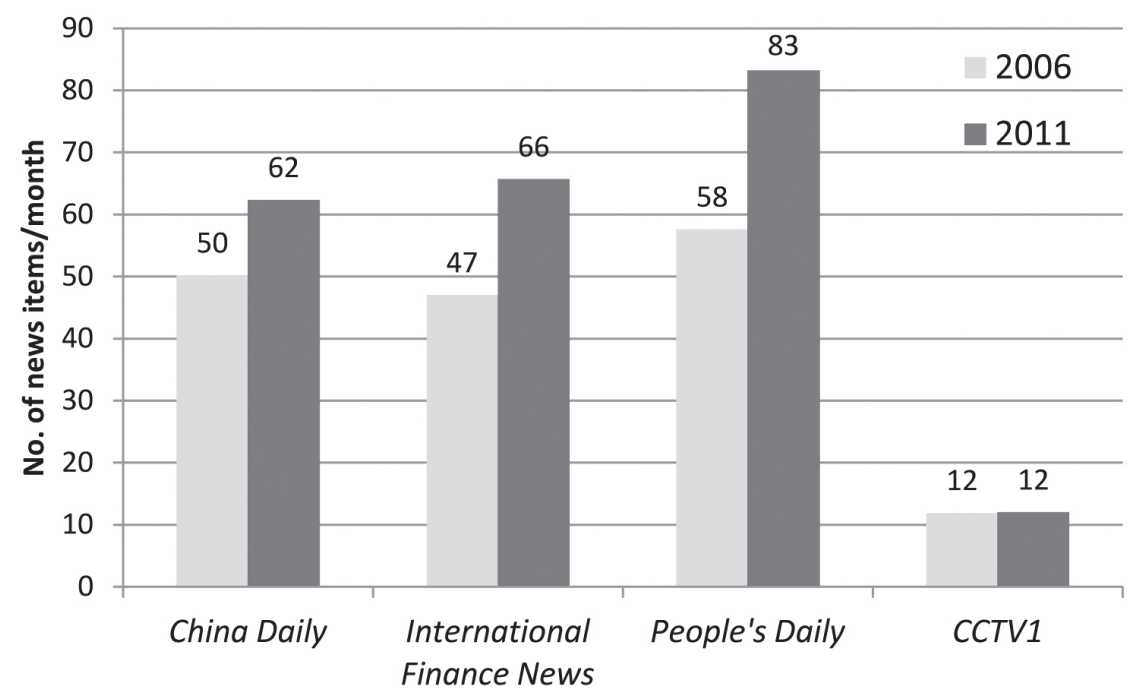

3 In the 2011 phase, "euro" was added as a search term. Out of 1,361 news items in the 2011 dataset, only 22 news pieces were found mentioning eurozone alone without any other key search terms. Thus, when comparing the volume of EU coverage across the time, this paper excludes these 22 pieces. 
Predictably, in all four media outlets the 2011 data demonstrated a heavier focus on the EU's economic activities (Fig. 2). Proportionally, the EU was framed more frequently in economic stories in the International Finance News and the China Daily. Interestingly, the 2011 People's Daily coverage displayed similar levels of attention to the EU's political and economic actions. In $C C T V-1$ prime-time news, the EU was predominately reported from a political angle, but the share of EU economic news increased compared with 2006. The image of the EU as a social actor was the third most visible category in both 2006 and 2011; however, the overall visibility of such news decreased in the three of the four monitored news outlets in 2011. Regardless of the EU's continuous efforts in promoting environmental protection and sustainable development, and despite the impressive amount of developmental aid offered by the Union to the developing world every year, the EU's actions in environmental and developmental fields have largely failed to catch Chinese newsmakers' attention. It seems that the media portrayal of the EU in China's leading news media is not quite as comprehensive as the reality of the EU-China strategic partnership.

Figure 2. Thematic framing of the EU-related news in four Chinese media outlets, 2006 and 2011

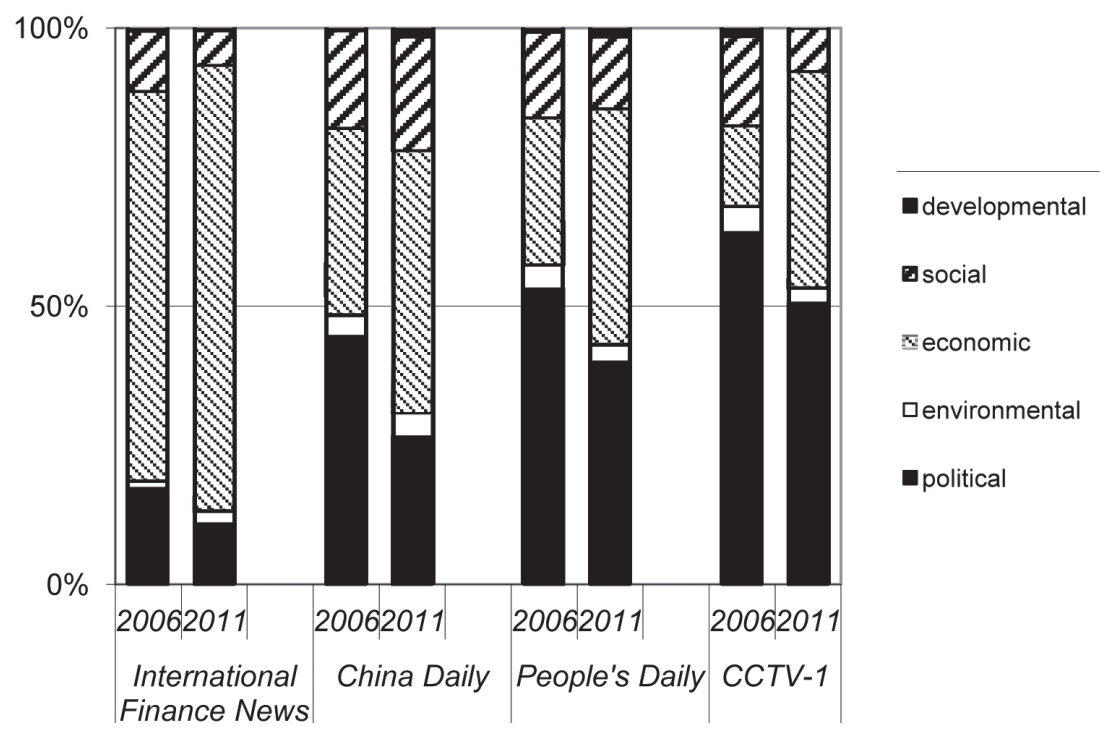

To assess the prominence of the EU as an economic power in 2006 and 2011, the monthly averages for each frame's reportage were compared. Table 1 demonstrates that, in terms of absolute numbers, all four news outlets covered a greater volume of EU economic stories in 2011. The monthly average of economic news coverage tripled in CCTV-1, and doubled in the People's Daily and China Daily. In the International Finance News, the volume of economic- 
framed EU news increased by an impressive 63 per cent. Unsurprisingly, it was stories on the eurozone debt crisis which accounted for the overall increase in EU economic news. This media preference for covering Europe's economic news resulted in a corresponding decrease in the monthly averages of EU stories in political frame, with the exception of the People's Daily.

Table 1. Change in monthly average number of EU news in each media frame, 2006 and $2011, \%$

\begin{tabular}{|l|c|c|c|c|}
\hline & $\begin{array}{c}\text { China } \\
\text { Daily }\end{array}$ & $\begin{array}{c}\text { International Finance } \\
\text { News }\end{array}$ & $\begin{array}{c}\text { People's } \\
\text { Daily }\end{array}$ & CCTV-1 \\
\hline Economic & +81 & +63 & +135 & +194 \\
\hline Environmental & +44 & +150 & +4 & -40 \\
\hline Social & +49 & -18 & +23 & -47 \\
\hline Developmental & +233 & no change & +225 & -100 \\
\hline Political & -24 & -7 & +10 & -13 \\
\hline
\end{tabular}

The distribution of topics within the economically-framed EU reportage shows some changes from 2006 to 2011 (Fig. 3). In 2006, the EU was featured most frequently as a trading power: a crucial trading partner and export destination of China and a key player in the World Trade Organisation. Another significant theme in the reportage was trade disputes between the EU and China. At the centre of attention were the anti-dumping duties on various products mutually imposed by the EU and China on each other, as well as anti-dumping duties and/ or non-tariff barriers implemented by the EU against its other trading partners. In 2011, EU trade-related stories still remained visible: in fact, the monthly average of EU trade-related news in the four news outlets in 2011 was almost at the same level as for 2006 (38.1 news items per month in 2006 and 37.3 news items per month in 2011). Bilateral trade relations, including disputes, once again constituted a large aspect of EU news coverage in China.

However, the dramatic increase in reportage of the eurozone sovereign debt crisis in 2011 "diluted" the centrality of EU trade-related news. Remarkably, the number of news items on the EU's state of economy in 2011 was more than twelve times of that found in 2006 ( 4 vs. 50 pieces of news per month in 2006 and 2011 respectively). Looking at the news outlets individually, CCTV-1 and the business daily International Finance News were particularly focused on covering the fiscal crises in the euro area (Fig. 4). Although the China Daily and the People's Daily continued to focus more on the EU's trading activities, their 
coverage of the state of economy also rose considerably. For the whole of 2006, only 2 news items on the state of economy were found from the China Daily while 20 articles on that topic were found in the People's Daily. In contrast, during the first half of 2011, the total of 67 and 63 articles in the China Daily and the People's Daily respectively focused on the EU's state of economy.

Figure 3. Sub-frames of EU economic news in four Chinese media outlets, 2006 and 2011

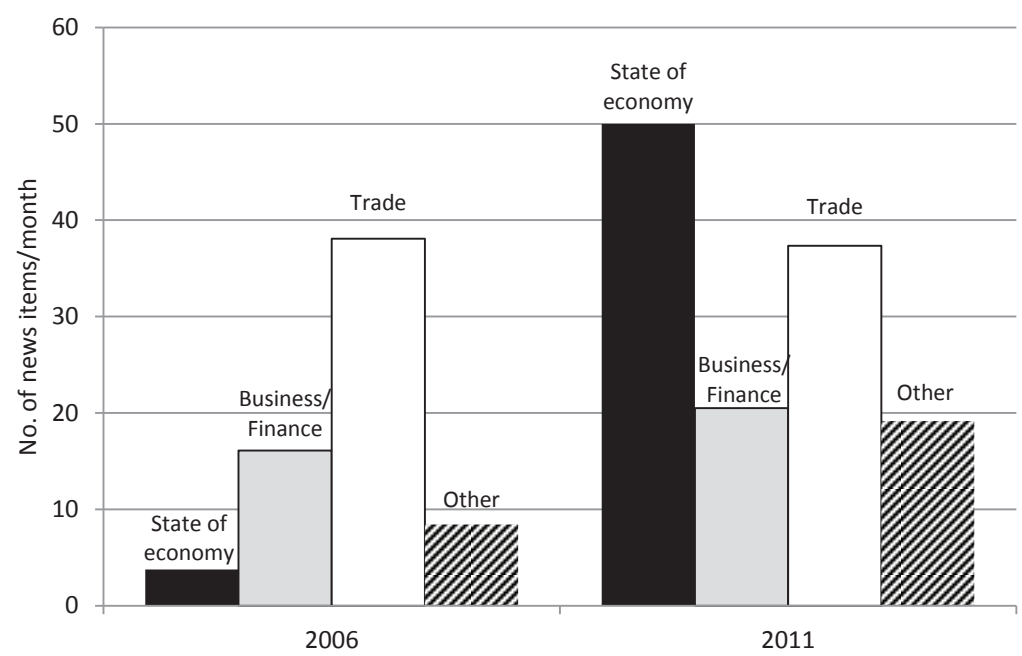

Figure 4. Sub-frames of EU's economic news in each media outlet in 2011

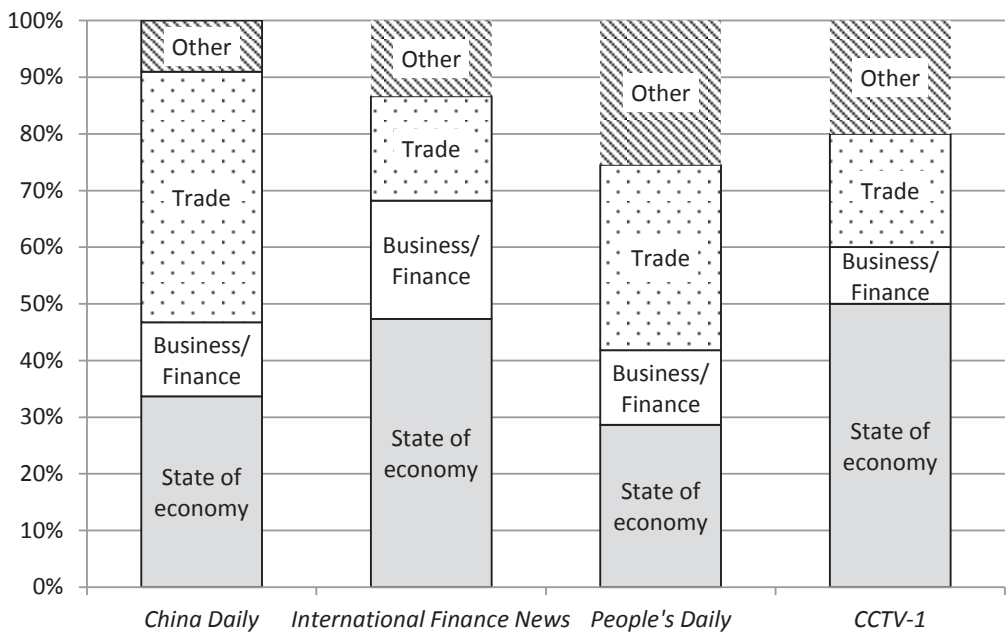

The most telling finding, however, was the shift in attitude in this reportage. Whilst 80 per cent of the state of economy news in 2006 portrayed positive 
economic growth in the EU/eurozone, 80 per cent of those in 2011 highlighted the financial turmoil in the EU/eurozone, particularly the situations of debt-laden Greece, Ireland, Italy, Portugal and Spain. Undoubtedly, the development of the financial crises in the EU captured China's media attention. While priority given to this topic did not result in a decrease of interest in other issues in absolute terms, the sheer amount of the debt crises news may have given readers an impression that the financial crisis was the single dominant EU economic issue. Instead of profiling an influential and powerful trading bloc (as portrayed in 2006), the 2011 coverage framed the EU as a problematic and crippled economy.

Reflecting the financial situation in several indebted Member States, the overall representation of the EU's economic actions in 2011 was more negative than that in 2006. In particular, Figure 5 illustrates that the tone of reportage on the EU's state of economy in 2011 was much more negative than that in 2006. Concerning the EU's other economic actions, the evaluation in 2011 was only slightly more negative than in 2006. As such, it is plausible to conclude that the outbreak of the debt crises in the eurozone negatively affected the overall image of the EU as economic power in the leading Chinese news media.

Figure 5. Evaluation of EU economic news in four Chinese media outlets, 2006 and 2011

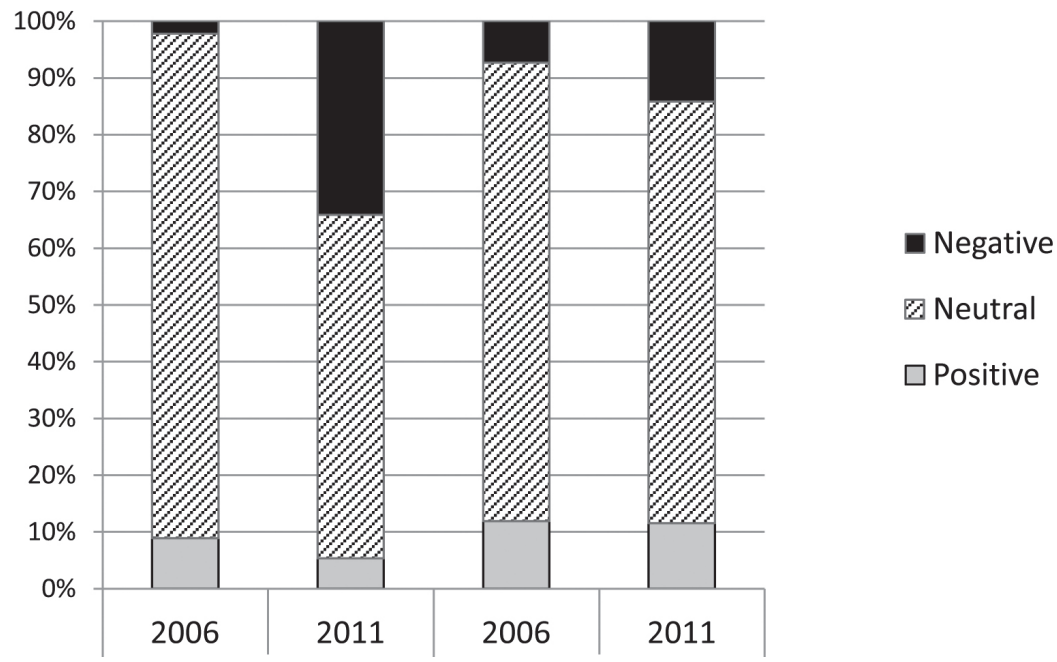

In 2011, all three newspapers were more negative than positive in tone when reporting the economic situation in the EU (Fig. 6) (with the popular daily and the business daily assigning the heaviest negative evaluations). Yet, remarkably, the largest portion of the reportage in all outlets engaged an unprejudiced tone and presented the facts neutrally. Somewhat differently, the television news 
broadcast presented a more or less balanced distribution of positive and negative evaluations when talking about the EU's state of economy.

Figure 6. Evaluation of EU's state of economy news in 2011 in each media outlet

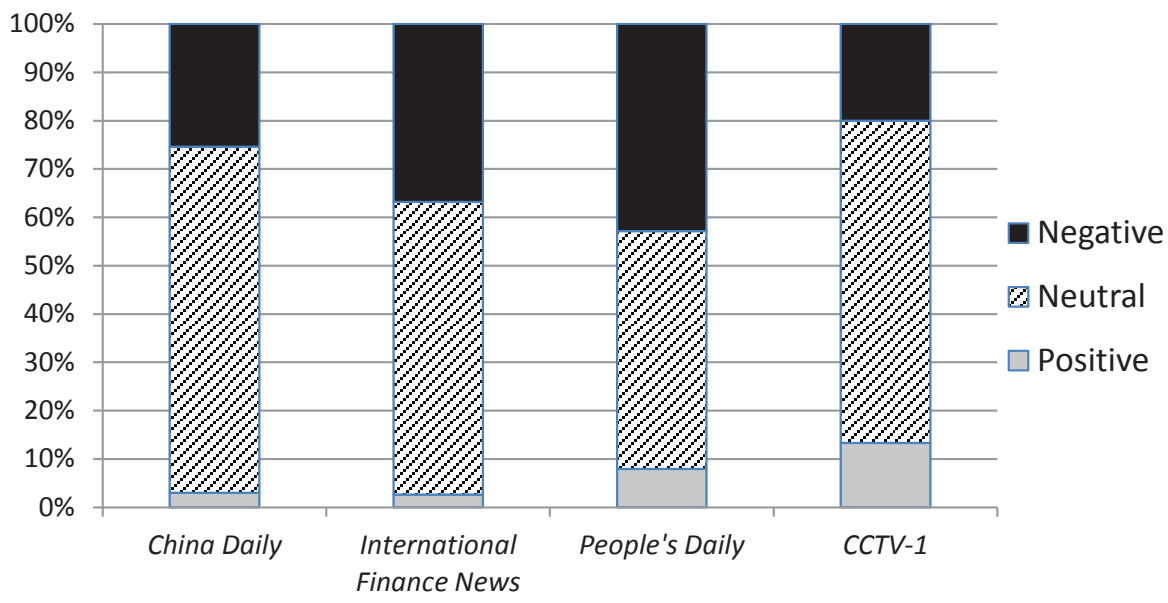

A more nuanced insight - using the tool of the metaphors - revealed that the reportage of the eurozone economy in 2011 was crammed with highly negative images of the economic situation in Europe: the EU's economy was most frequently compared to a body suffering from "disease/sickness" as well as inability to "move forward". A gambling metaphor-a "domino effect"-was also often used. The debt crisis was often described as a highly contagious disease or fire which could spread quickly from one eurozone member state to another (a metaphor that appeared in 25 different news articles among the 300 state of economy news collected in 2011). The EU economy was said to be sick, physically handicapped and in need of medication (in more than 10 news articles). The economic situation in the EU as well as its Member States were depicted as being stuck in the mud or struggling hard to move forward in a dozen of news items analysed. The financial turmoil as well as possible national debt defaults of Greece, Ireland, Italy, Portugal and Spain was repeatedly described as a "domino" (appearing in 9 news articles), in which an "explosion" in one country would lead to a series of explosions in the eurozone (found in more than 10 news items). However, the newly coined (if rather derogatory) acronym "PIIGS", referring to Portugal, Italy, Ireland, Greece and Spain and widely used internationally, was seldom found in the monitored Chinese news media. In the 500 news items collection from the People's Daily, only 2 articles mentioned PIIGS; while only 3 out of 402 news items collected from the International Finance News did so. The term was completely absent from the China Daily 
reports and $C C T V-1$ prime-time news broadcast.

Metaphors were also used by the newsmakers when they were conceptualising China's reaction to the eurozone debt crisis. Significantly, all metaphors used in this context portrayed the role of China in a positive light: China offered a "helping hand" to partners in the eurozone (Wang, 2011a; Wu et al., 2011), which was an act like "sending coal to somebody during snow" (雪中送炭 is a proverb in Chinese language) (Wang, 2011a, p. 4). On the other hand, the EU countries were said to "board the China Express or China boat" so as to exit the problematic situation (China Daily, 2011; Zhou, 2011, p. 8).

Apart from the changes in volume, evaluation and focus, comparison between news reportage of the EU in 2006 and 2011 also revealed a change in the visibility of the main representatives of the Union in the Chinese media. In 2006, the most visible economic actor was the European Commission (EC), a communal institution (Fig. 7) which far exceeded the visibility of any individual Member State. In terms of its appearance per month, the EC was mentioned more than twice as often as any of the EU Member States. A drastic change was observed in 2011. First, the European Central Bank (ECB) became the most frequently mentioned EU institution in the economic field. The outbreak of the sovereign debt crisis contributed to a higher external profile of the ECB and saw it replace the EC as the EU's most profiled institution in economic field. Second, individual Member States were much more frequently featured, especially the PIIGS countries, with Greece becoming the second most visible EU Member State in China's EU-related economic news.

Figure 7. EU actors in the economic news per month, 2006 and 2011

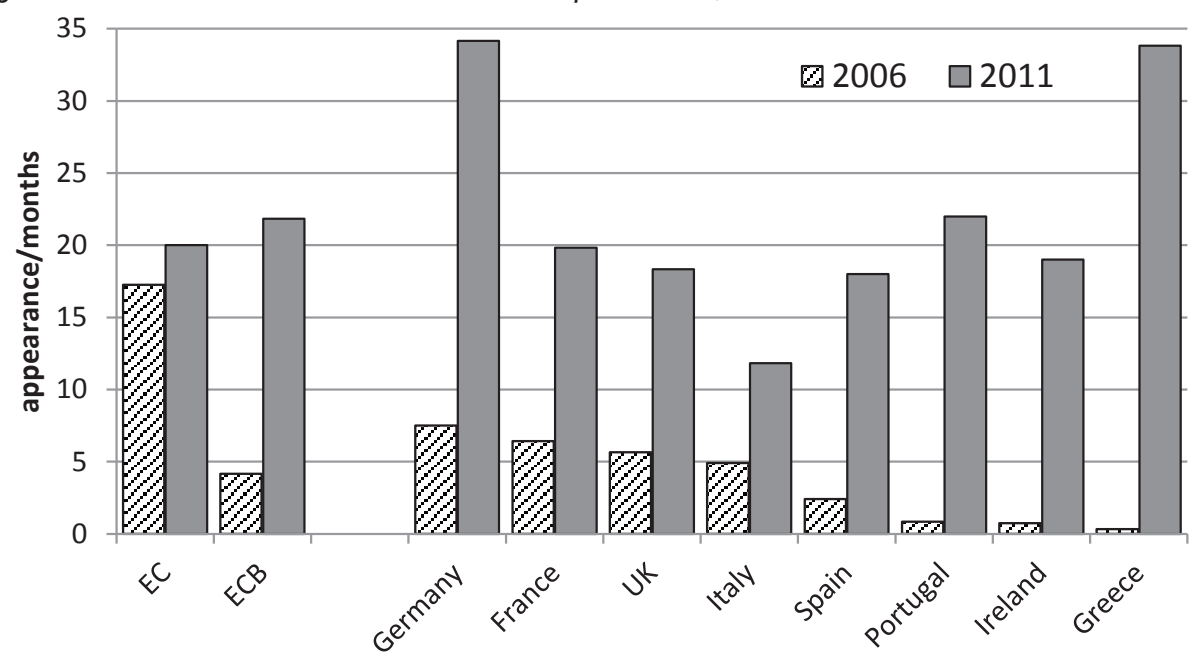


In the 2006 dataset, the so-called "EU-3"- Germany, France and the UK-were the most frequently mentioned EU Member States both in economically framed news and in politically and socially framed news. Their individual visibility was far higher than any of the other Member States, including Italy and Spain. This was no longer the case in 2011. In economic news, Germany's appearance stood out among the EU-3. The UK, which is not a part of the eurozone, featured less often than most of the PIIGS countries. The "EU-3 leadership" seemed to be weakened by the crises in the euro area. Germany as the leading economy in the EU replaced an EU led jointly by France, Germany, and the UK in economic field.

Furthermore, in the 2011 dataset, the distribution of the most visible EU actors in economic news and non-economic news differed (Fig. 8). Focusing on those EU news items that were about anything else other than economics, the Commission, understandably, was far more salient than the ECB; however, its visibility was lower than those of the Big Three countries-Germany, France and the UK. The UK was featured as frequently as Germany as one of the EU most evident actors. On the other hand, the debt-laden eurozone countries were discussed much less frequently in news with non-economic frames.

Figure 8. EU actors in economic news items and non-economic news items in 2011

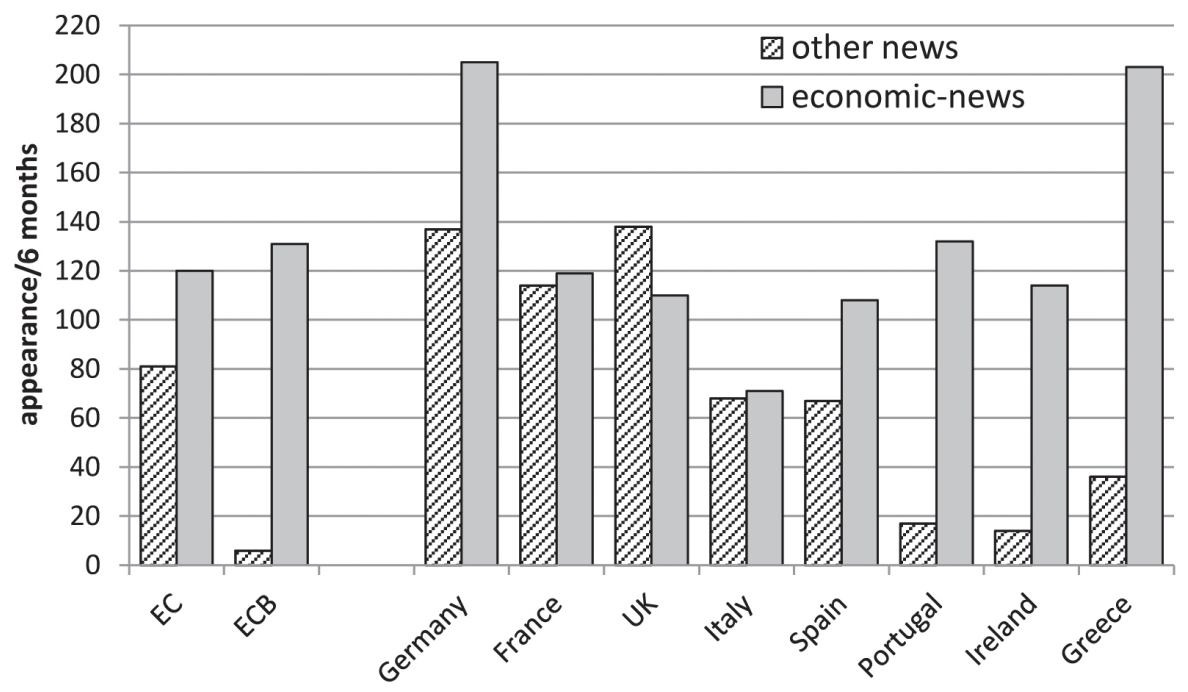

The above analysis tells us that the eurozone sovereign debt crisis has dramatically influenced how the EU was represented by the Chinese news media. The four monitored Chinese media prioritised reporting the EU's economic issues in 2011 in comparison with 2006. This led to a decrease in the EU's visibility in other areas, particularly in the political field. Importantly, within the reportage 
of EU economic affairs, the previously dominant image of the EU as a strong trade power (2006 study) has been substantially diluted by the stories reporting the EU's problematic state of economy, with the key focus on the eurozone debt crisis. Moreover, the negativity of EU economic reporting has increased, mostly as a reflection of the ongoing sovereign debt crisis in several eurozone member states. In this context, the dominant EU actor in the economic field was no longer the European Commission (the 2006 study) but the European Central Bank (the 2011 study), and individual Member States engulfed by the crisis (either as saving or ailing actors), such as Germany, Greece and Portugal, have become more prominent actors than the EU's traditional Big Three.

\section{Changes in the perceptions among Chinese elites}

In the two rounds of elite interviews conducted in China, all interviewees were asked to comment whether they saw the EU as a great power. Comparatively, the results in 2011 were slightly less positive than those in 2007, albeit still enthusiastic: 71 per cent of the Chinese interviewees perceived the EU as a great power in 2007 vs. 60 per cent in 2011 (Fig. 9). While only 3 per cent of the respondents in 2007 did not see the Union as a great power, in 2011 the share of these responses increased to 8 per cent, although the majority of Chinese elites in 2011 agreed that the EU possessed great power generally or in certain fields.

Figure 9. Chinese elites' responses to the question whether the $E U$ is a great power

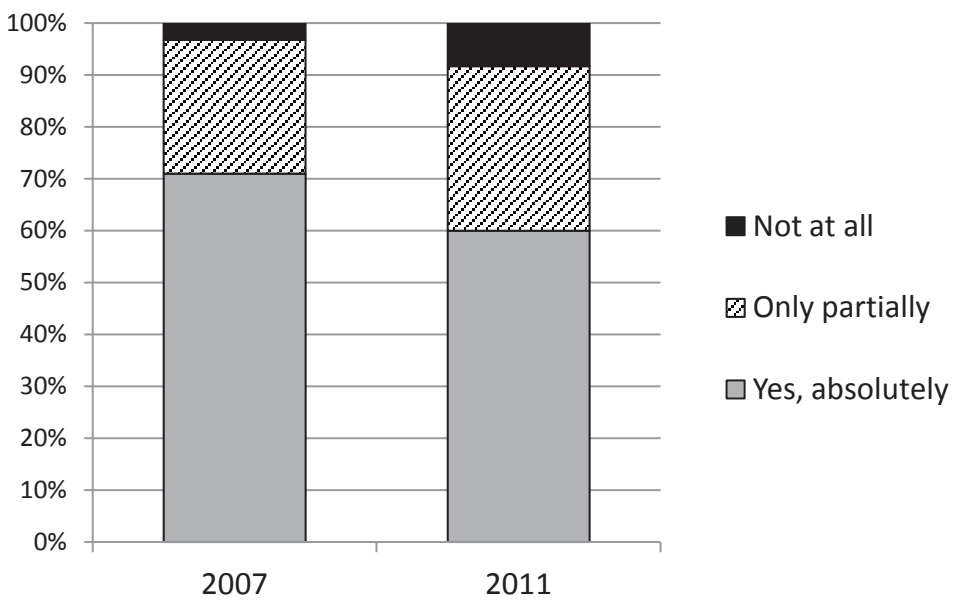

In the 2007 dataset, the most common responses featured references to the Union's economic strength and added-value of integration (i.e. how integration 
made the EU a great power). One civil society elite explained, "being an organisation of such significant scale, it [i.e. the EU] certainly is influential on the world stage. In international affairs, foreign relations and other areas, it speaks in a loud voice." His counterpart from business field elaborated,

I think it [the EU] is a great power. Firstly, we look at its economy: its members, like the UK and Germany, are strong countries themselves. Now they integrated into one so that the EU becomes another strong economic power in the world, which is equivalent to the US and Japan. Moreover, after uniting, the EU gets more weight in politics and a louder voice, which would probably increase Europe's bargaining power against the US. I think this is good to international politics, making it more multipolar and democratic.

Intriguingly, the outbreak of the eurozone debt crisis did not change these images in the eyes of Chinese stakeholders. In the 2011 findings, the majority of interviewees remained confident in the EU's economic power. As one media elite noted, "Of course the EU is a powerful force. Its economic strength is very strong; the GDP is the top of the world. What's more, it is China's largest trading partner." Only one interviewee saw a decline in the EU's economic power. Generally, as shown in Figure 10, the Union's economic power remained the most recognised in the eyes of these Chinese elites. However, the images of the EU as a great power in the political field were more ambiguous. While 10 per cent of respondents in 2007 and 15 per cent in 2011 particularly noted that the EU failed to be a politically great power, 35 per cent of interviewees in 2007 and 42 per cent in 2011 thought the opposite.

Interview responses in 2011 echoed the Chinese government's official foreign policy discourse which favours multilateralism and the formation of a multipolar world order (Chan, 1999; China, 2003; Wang, 2005; Li, 2012). Accordingly, the EU was seen by the elites as one of the significant poles in the world together with such powers as the US, Japan, Russia, and China itself.

Importantly, when responding to the follow-up question "Do you see the EU as a leader in international politics?", Chinese elites commonly denied the Union having a leadership capacity. They perceived the EU as one of the world powers, which was weaker than or dependent on the US, as well as lacking cohesion to act as a powerful unity.

The vision of the EU's economic strength dominating all other areas was confirmed by the responses outlining the spontaneous (stereotypical) images of the EU. The interviewees were asked "When thinking about the term 'the 
European Union', what three thoughts come to your mind?" Results from both the 2007 and 2011 surveys frequently featured economy-related images, namely, economic union, economic cooperation, strong economy, and trade (Figs. $11 \& 12$ ). Significantly, despite a rather short life-span, the euro currency became the most typical EU image among the Chinese elites in both 2007 and 2011. The fact that the common currency has not yet been adopted by all EU Member States did not seem to affect this trend. The frequency of the euro being named as a spontaneous association was even higher in 2011 than in 2007: of the interviewees 38 per cent named it as a symbol of the EU in 2011, while only 17 per cent of the interviewees in 2007 did so. Indeed, in the 2011 dataset, the image of the euro was far more visible than any other listed EU-related images.

Figure 10. The policy areas in which the interviewees saw the EU's power

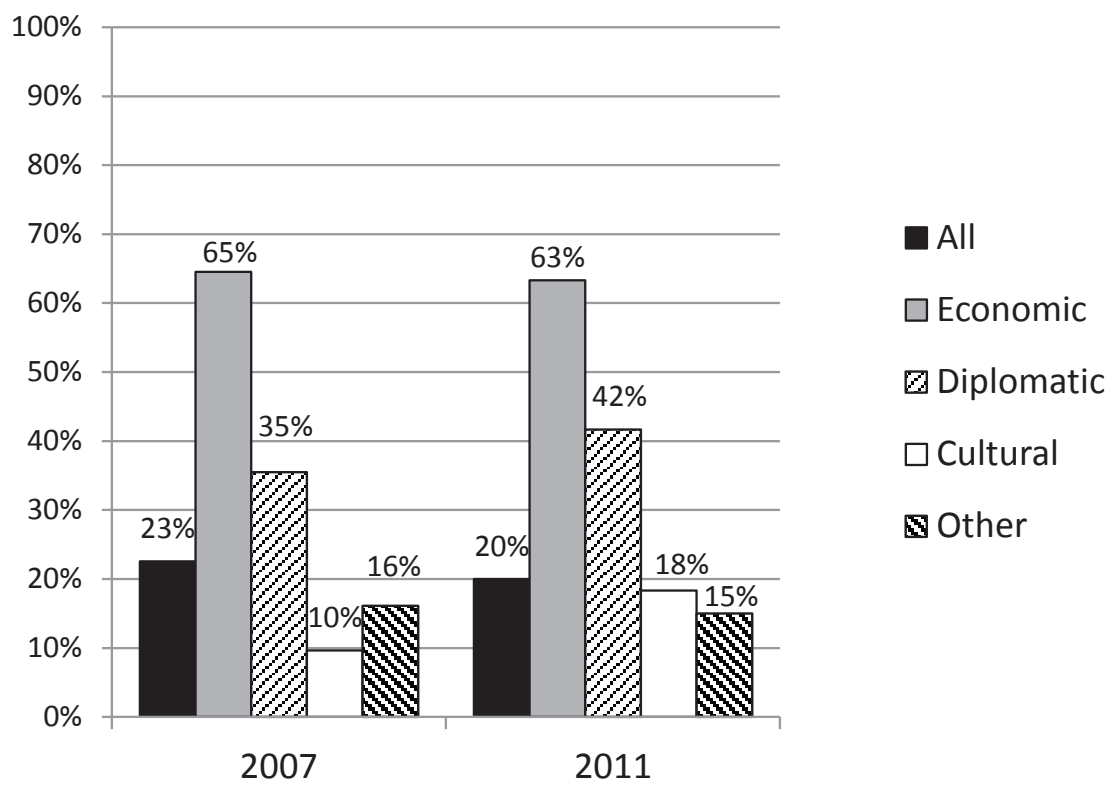

Predictably, these 2011 responses featured new spontaneous images of "crisis" and "debt" reflecting the awareness of the financial problems in the EU. Probably more concerning is that there were no longer references to the EU as a model for the Asian regionalism in 2011, hinting at a rising scepticism towards the Union's integration project among the Chinese elites. Mirroring the media analysis, in the eyes of these stakeholders, Britain became less prominent in the context of the EU, while France and Germany remained visible in relation to the EU. 
Figure 11. Word cloud of the three spontaneous images by Chinese elites in 2007

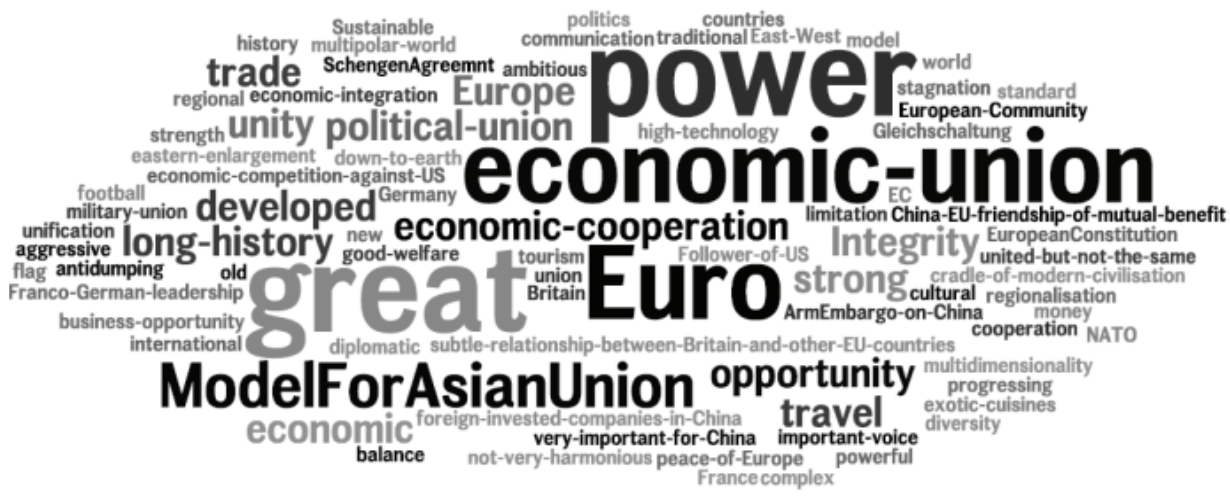

Figure 12. Word cloud of the three spontaneous images by Chinese elites in 2011

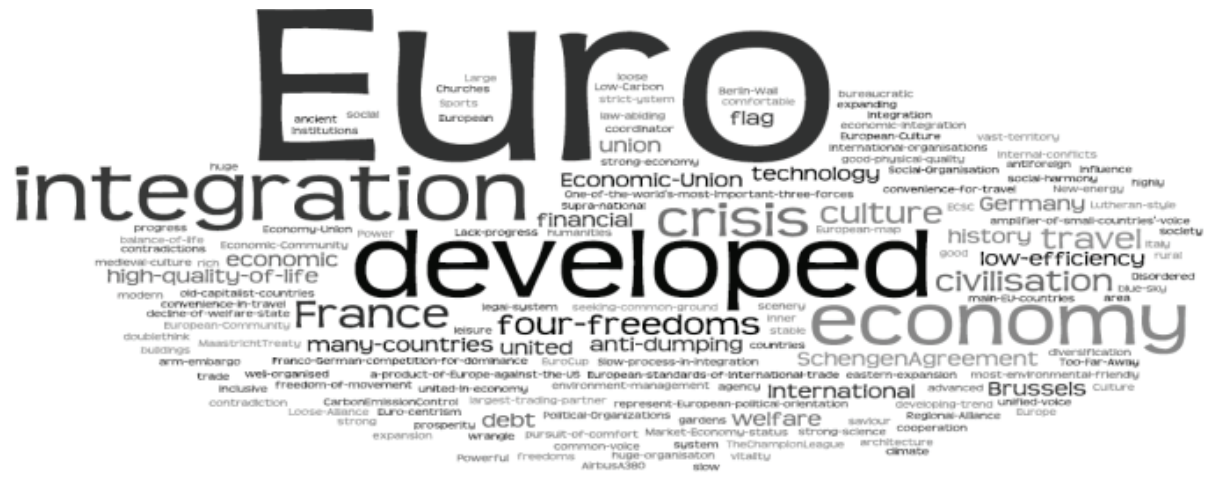

The questionnaire specifically asked respondents to compare the euro as an international currency vis-à-vis the US dollar. Findings from 2007 and 2011 confirmed that Chinese elites viewed the US dollar to be of higher international relevance than the euro. Although many pointed out that the euro had been stronger and more stable than the US dollar, few respondents (one in 2007 dataset and one in 2011 dataset) thought that the euro had replaced or would replace the US dollar's domination as the most popular international currency. In 2007, of the interviewees 26 per cent described the euro as a balance to the US dollar and an additional option for both China and the international community as a currency for transactions as well as for foreign reserves. In contrast, by 2011 only 14 per cent of respondents thought so.

Furthermore, the tone of the 2011 comments on the euro was generally more negative than that in 2007 (Figs. $11 \&$ 12). One-fifth of the interviewed Chinese elites in 2011 gave rather negative remarks, especially among the political decision-makers. For example, one politician said that "the recent euro debt 
crisis hit people's confidence on the euro, although I do not think the euro will go bankrupt. I want the euro to be as strong as the US dollar, but it is far from the reality." Another political elite commented, "The euro lacks energy, [it is] fatigued... In international financial market, the euro is not strong compared with the US dollar. For personal investment, I will choose the US dollar."

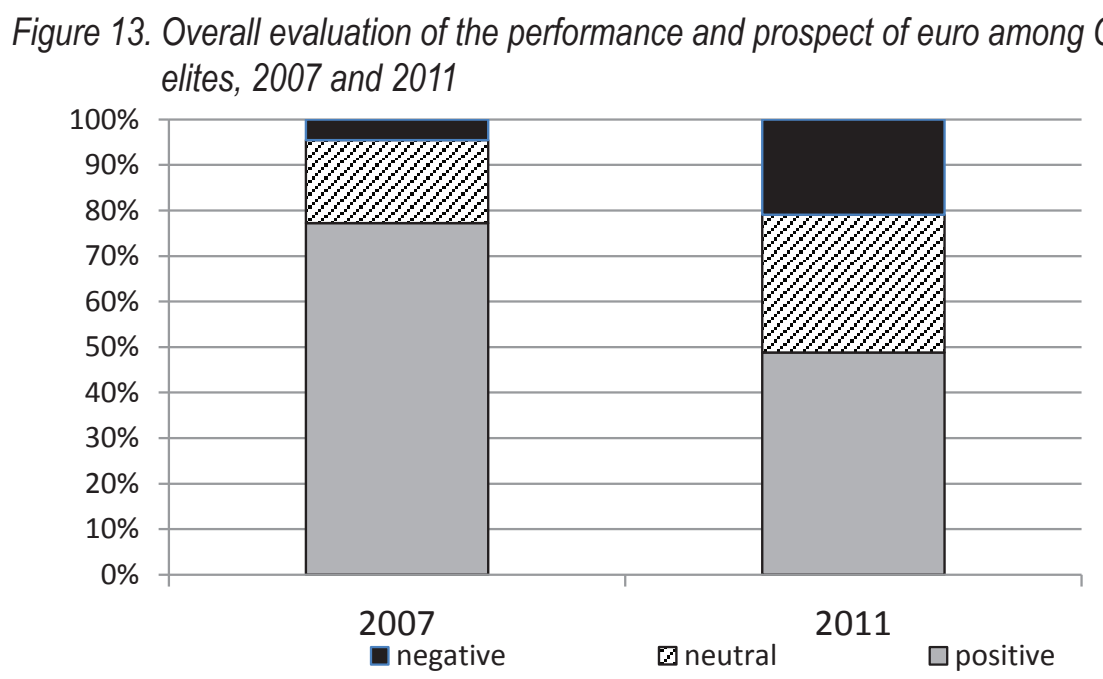

The above analysis tells us that the eurozone sovereign debt crisis did negatively influence the perceptions of the EU as an economic power and the euro as an international currency among the Chinese elites. However, this negative shift, while perceptible, was not enormous. The EU's most recognised strength still lies within the economic field. Elite interviewees keep holding on to the opinion that China needs a strong EU as one pole in the multipolar world order, despite the negative news on the euro and the eurozone sovereign debt crisis. Moreover, the euro has become the most distinct symbol of the EU in the 2011 study, even though a number of the interviewed elites indicated a more reserved attitude towards its capacity to perform as an international currency.

\section{Discussion and conclusion}

In sum, China's media and national elites perceived the EU mostly as an economic and political actor both prior to - and after - the outbreak of the eurozone sovereign debt crisis. However, the empirical findings indicate that the Union's political actorness had become slightly diluted by 2011 as more attention was devoted to Europe's economic and financial situation. Arguably, 
the reality of a high trade volume between the EU and China contributed largely to the prominence of the Union's economic actorness in the eyes of Chinese news media and elites. Furthermore, the sovereign debt issues triggered an increase in media coverage of the EU in the four monitored news outlets (which included the most authoritative newspaper People's Daily and the most widely disseminated television news broadcast on $C C T V-1$ ). The euro was named by the Chinese elites as symbolic of the EU much more frequently than any other concepts, events or personalities. Although since 2010 China and the EU have increased the comprehensiveness of their strategic partnership by including foreign affairs, security, climate changes and global economy governance, the media imagery and elite perceptions of the EU in China has yet to take note of this development and diversify accordingly.

The comparative analysis has shown that both Chinese media portrayals and elite views of the EU's economic power have slightly deteriorated between 2006/2007 and 2011. The several fiscal crises-engulfed EU Member States, as well as series of failed attempts among the EU Member States to resolve these problems, were key factors that caused a more negative tone in the coverage of the state of European economy than for reports on other economic matters. The credibility of the euro as an international currency in the eyes of the interviewed elites also slightly declined. Overall, the rising profile of the financiallydistressed PIIGS countries and the euro in China has had a perceptible as well as negative impact on the external image of the EU and the eurozone.

This notwithstanding, a considerable number of news items and interviewed elites pointed out that China still wanted and needed a strong EU and strong euro. China's preference for a multipolar world order, recognition of the EU's economic might and intention to diversify its reserve holdings (to reduce dependence on the US dollar) have been decisive factors behind China's decision to not reduce its euro-denominated assets. In 2010 and 2011, the Chinese government actually purchased more eurozone national bonds as well as the bonds issued by the European Financial Stability Facility (Milne, 2011; The Financial Times, 2011a; $\mathrm{Ng}, 2011 ; \mathrm{Li}, 2012)$. Yet, from the analysed Chinese news reportage and views of several Western commentators (such as Hille \& Anderlini, 2012; The Financial Times, 2011b), China has become more cautious, if not reluctant, in purchasing more bonds issued by eurozone nation states or the European Financial Stability Fund since the last quarter of 2011. This case demonstrates how perceptions (decreasing credibility of the euro and the EU's economic power in China) may have shaped an agent's behaviour (China's reserved attitude in buying the newly issued eurozone bonds in 2011 and 2012), although the changed perceptions may not be the only reasons to change behaviour. 
It should be noted that the majority of the reportage on the state of EU economy in the Chinese news media featured the sovereign debt crises in terms of the problems inside the EU. Hardly any news items mentioned the possible impact of such crises on China; and this is despite the fact of the EU being the country's top trading partner. On the other hand, the EU's various efforts in resolving the debt crisis have been highly visible in the Chinese news reports. Arguably, the framing of the eurozone debt crisis as a problem only within the EU and the confidence shown in the news reports that the eurozone debt crisis can be eventually solved delivered the message that the Chinese media do not want the reportage of the eurozone debt crisis to make the EU look any less promising or any less important for China. This implied the Chinese government's view of the EU as China's significant partner and a power in the international arena. With its overall strength and international influence, China still sees the Union as one key pole in the multipolar world.

Furthermore, among the few news items which did mention China, this world's second largest economy was assigned the role of an "aid provider" to the EU. From the Chinese perspective, the reportage delivered the message of China helping to save the EU economy. The few initiatives taken by the Chinese government, such as sending trade delegations to EU nations and not decreasing the percentage of euro held in its foreign reserve, were framed as China being a good strategic partner of the EU. A few news items and interviewed elites pointed out that it was also in China's interest to belief in the euro so as to diversify its foreign reserves away from the US dollar. These views emphasise that China now has the capacity to give some help to the EU and EU-China relations can be further improved. Arguably, the perception of a slightly reduced EU economic power could be one explanation behind China's recent reiteration of its demand for the Union to lift the arms embargo and to recognise China's market economy status. That the EU was seeking help from China might have given China leverage for bargaining.

All things considered, a prolonged financial/debt crisis in the EU and its Member States did challenge the EU's image as a global economic powerhouse in China, yet, it has not been the only factor determining the changing Chinese perceptions of the EU. This research found that China's preference for a multipolar world order and the fact that the EU has been China's top trading partner were also significant in shaping Chinese perceptions of the EU in long term. In contrast, actions taken at the highest diplomatic level to make the EU-China strategic partnership more comprehensive were not found to have translated into influencing perceptions of these relations. As suggested by the constructivist theorists, the resulted perception influences the decision-making of China when 
managing relations with the EU. Therefore, to facilitate a truly comprehensive and strategic EU-China relationship, it is crucial for the two parties to perceive each other as comprehensive and strategic partners.

Dr. Lai Suet Yi (Cher) finished her doctoral studies in National Centre for Research on Europe, University of Canterbury, in 2012. Her PhD thesis focuses on the contribution of Asia Europe Meeting (ASEM) on Asia-Europe relations, regionalism and interregionalism. Cher obtained her bachelor's degree in European Studies from Hong Kong Baptist University in 2006. Her Honours paper was "The role of France in the Treaty of European Constitution". Since 2006 she has been a researcher at projects 'EU in the Eyes of Asia' and 'Asia Through the Eyes of Europe', published numerous research papers on the external image of the EU, Asia-Europe relations, China-Europe relations and ASEM. Between July and October 2010, Cher completed an internship in World Programme desk of the European Policy Centre (Brussels-based think tank). Since September 2012, she has been academic manger of a new transnational research project 'External Images of the EU: Images of the EU as Normative Energy Player', which involved the BRICS countries as well as the EU Big Three. She served as post-doctoral Fellow at the Europe and EU Centre of Monash University, Australia, in April and May 2013. At present, Cher works as Research Associate at the School of International Studies, Peking University, and is responsible for the transnational project 'Challenges of European External Energy Governance with Emerging Powers: Meeting Tiger, Dragon, Lion and Jaguar'.

Dr. Li Zhang is lecturer in International Media and Culture at the University of East Anglia, UK. She holds a PhD in Communications Studies from the University of Leeds, UK. Apart from articles in peer-reviewed journals, she is the author of News Media and EU-China Relations (Palgrave Macmillan, 2011). Her research is interdisciplinary and focuses on mass communication and foreign policy, media and politics, news management and public diplomacy, EU-China relations, and EU perceptions in Asia.

\section{References}

Chan, G. (1999), Chinese Perspectives on International Relations: A Framework for Analysis, New York: St. Martin's Press. http://dx.doi.org/10.1057/9780230390201 China (2003), "China's EU Policy Paper," Beijing: Ministry of Foreign Affairs of the People's Republic of China, 13 October 2003.

China Daily (2011), 'China's message to EU,' China Daily, 27 June 2011, p. 8.

EU Council Secretariat (2012), 'Factsheet: EU relations with China, Beijing,' 14 February 2012. Retrieved from http://consilium.europa.eu/uedocs/NewsWord/EN/ foraff/127836.doc [accessed 20 May 2012] 
European Commission (1995), 'A Long Term Policy for China-Europe Relations,' Communication from the Commission, COM(1995) 279 final, Brussels, 5 July 1995. — (1998), 'Building a Comprehensive Partnership with China,' Communication from the Commission, COM(1998) 181 final, Brussels, 25 March 1998.

_ (2003), 'A Maturing Partnership - Shared Interests and Challenges in EU-China Relations,' Commission Policy Paper for transmission to the Council and the European Parliament, COM(2003) 533 final, Brussels, 10 September 2003.

The Financial Times (2011a), 'Dough boat to China,' LEX Column, The Financial Times, 29 October 2011, p. 16.

(2011b), 'China and the EFSF,' LEX Column, The Financial Times, 4 November 2011, p. 14.

Hille, K. \& Anderlini, J. (2012), 'China reviews its EU crisis role,' The Financial Times, 3 February 2012, p. 2.

Hu, Y.-W. (2010), Management of China's foreign exchange reserve: a case study on the state administration of foreign exchange ( $S A F E$ ), European Economy - Economic Papers, no. 421 (July 2010), Brussels: European Commission.

Holland, M. et al., eds. (2007), The EU through the Eyes of Asia, Warsaw \& Singapore: University of Warsaw.

Holland, M. \& Chaban, N., eds. (2010), Reflections from Asia and Europe: How do we perceive one another? Special issue of Asia Europe Journal, vol. 8, no. 2.

Jervis, R. (1976), Perception and Misperception in International Politics, Princeton, NJ: Princeton University Press.

Li, Z. (2012), 'What China wants in 2012,' Project Syndicate, 12 January 2012. Retrieved from www.project-syndicate.org/commentary/what-china-wantsin-2012 [accessed 1 May 2012]

Men, J. (2006), 'Chinese perceptions of the European Union: A review of leading Chinese journals,' European Law Journal, vol. 12, no. 6, pp. 788-806. http://dx.doi.org/10.1111/j.1468-0386.2006.00346.x

Milne, R. (2011), 'Good news from China is not all it seems for bonds,' The Financial Times, 4 September 2011.

Ng, T. (2011), "Premier on EU mission to boost trade China unlikely to be Europe's saviour, although Wen will promote investment on continent," South China Morning Post, 25 June 2011.

Ruggie, J. G. (1988), 'What Makes the World Hang Together? Neo-utilitarianism and the Social Constructivist Challenge,' International Organization, vol. 52, no. 4, pp. 855-885. http://dx.doi.org/10.1162/002081898550770

The Financial Times (2011a), 'Dough boat to China,' LEX Column, The Financial Times, 29 October 2011, p. 16.

(2011b), 'China and the EFSF,' LEX Column, The Financial Times, 4 November 2011, p. 14. 
Shambaugh, D. (2008), 'China eyes Europe in the world: Real convergence or cognitive dissonance?' in D. Shambaugh, E. Sandschneider \& H. Zhou (eds.) China-Europe Relations: Perceptions, policies and prospects, London: Routledge, pp. 127-147.

Wang, J. (2005) “China's Multilateral Diplomacy in the New Millennium," in Y. Deng, \& F.-L. Wang (eds.) China Rising: Power and Motivation in Chinese Foreign Policy, Lanham \& Oxford: Rowman \& Littlefield Publishers, pp. 159-200.

Wang, L. (2011a), "No good sign in the new year: 'Titanic tragedy' reappear - Euro zone may be turned over by the second round of crisis” [新年没有好兆头， “泰坦尼克” 悲剧重演 第二轮危机或砸沉欧元区], International Finance News, 4 January 2011, p. 4.

(2011b), 'Japan: To safe Euro, count me in!' [日本：救欧元，算上我！], International Finance News, 12 January 2011, p. 4.

Wendt, A. (1992), 'Anarchy is what states make of it: the social construction of power politics,' International Organization, vol. 46, no. 2, pp. 391-425.

- (1994), 'Collective Identity Formation and the International State,' American Political Science Review, vol. 88, no. 2, pp. 384-96. http://dx.doi.org/10.2307/2944711

Wu, C.; Ding, G. \& Ji, P. (2011), 'Greek government passed confidence vote, good news for Asian financial market,' [希腊政府通过信任投票对亚洲金融界来说是 利好消息 欧债危机对亚洲经济负面影响有限], People's Daily, 23 June 2011.

Zhang, L. (2011), News Media and EU-China Relations, New York: Palgrave Macmillan. http://dx.doi.org/10.1057/9780230118638

Zhou, W. (2011), 'Cooperate for better future,' China Daily, 27 June 2011, p. 8.

Zhu, L. (2008), 'Chinese perceptions of the EU and the China-Europe relationship,' in D. Shambaugh, E. Sandschneider \& H. Zhou (eds.) China-Europe Relations: Perceptions, policies and prospects, London: Routledge, pp. 148-173. 